\author{
Colloquia Litteraria \\ UKSW \\ $1 / 2018$
}

ANITA JARZYNA

\title{
RAFAŁ WOJACZEK: "NORWID SAYS HELLO, THERE IS NO DOUBT THAT I HAVE READ A POEM OF HIS"1
}

To Kasia Górecka, when she reads Wojaczek again

At the beginning - in the title and below-I am quoting words which do not reveal the manner of Norwid's reception in the works of Wojaczek. The phrase, written by him in August 1966 in Mikołów in the journal Dla Teresy (For Teresa) ${ }^{2}$, only prefigures this reception.

Muzyka To Ty myślisz o mnie

Co Ty wiesz o mnie - kiedy czasem zegarek

Ci upadnie...

Ty jesteś skromna - a ja żyję

Ja umiem być - Ty

jesteś...

Ty jesteś starsza, o mnie ${ }^{3}$

(RWKB, 162-163)

\footnotetext{
1 R. Wojaczek, Dziennik dla Teresy. Quoted in M. M. Szczawiński, Rafał Wojaczek, który byt, Katowice 1999,. 162. (Hereafter: RWKB). I am grateful for all the remarks about this sketch to: Prof. Katarzyna Kuczyńska-Koschany

${ }^{2}$ Wojaczek wrote this journal to Teresa Ziomber, a woman he was connected with for longer than with any other woman and to whom he dedicated his first volume of poetry: Sezon (Season) (1969).

3 "Music You think of me/What do You know about me-when sometimes a watch/You drop[...]/You are humble-While I am live/I know how to be/You are [...] older than me."
} 
It was exactly during his work on the last version (there were six of them in the journal) of this poem, entitled "Ty jesteś starsza" ("You Are Older"), which was not published later in any of his volumes, that Wojaczek wrote: "My dear, Norwid says hello, there is no doubt that I have read a poem of his". The note comes from 18, or 19 August, and is one of the few auto-interpretations of Wojaczek and one of the two, of which I know, of his statements about his reading of Norwid. He admitted here inspirations so delicate that they are practically imperceptible.

A day earlier, when the first version of the poem was being written, Wojaczek, as if he wanted to be closer to the size of "Czułość" ("Tenderness"), the most condensed of Norwid's miniatures (written not only 'succinctly', but 'super succinctly' as Przyboś described this poem of six lines ${ }^{4}$ ), he noted in his journal: "To say who one is in these six lines of the poem-I have accomplished it as well as I could. Six simple declarative sentences" (RWKB, 159-160). Wojaczek, however, did not manage to repeat the shape of Norwid's poem, and the association with "Tenderness" (if, for sure, we are concerned with this poem, which consists, after all, of six lines, but not of six sentences) survived only thanks to these phrases: "What do You know about me-when sometimes a watch/You drop[...]". In Norwid's miniature a watch "a widower used to wear on a braid made of blond hair" (PW, 2, 85).The association between these two poems can be found, perhaps, in the ending of each stanza with open lines (Wojaczek uses ellipsis twice, Norwid uses one ellipsis and then three hyphens). But the differences are huge: "Tenderness" in a brilliant manner describes different versions of the same emotion, while "You Are Older" is about a huge difference between the lyric "I" and female "You", and tenderness which happens in the asymmetrical (because "You Are older") relationship. The major difference is also in the degree of maturity of these two texts: Norwid's poem is a miniature masterpiece, while Wojaczek's is merely a poetic exercise. However,

4 J. Przyboś, Zdumiewajacy poeta, in Norwid. Z dziejów recepcji twórczości, ed. by M. Inglot, Warszawa $1983, \cdot 343$.

314 
A. JARZYNA, "WOJACZEK: "NORWID SAYS HELLO..."

in these seven lines, and particularly maybe in the last one, we have all this, which will turn out to be so important in later love poems, particularly in erotic poems influenced by Norwid's poem. Wojaczek's fascination with Norwid was, as it seems, one of Wojaczek's first literary fascinations. Jerzy Kronhold (a poet connected with 'Pokolenie 68' (Generation 68')), who was Wojaczek's friend when Wojaczek was a student of the Department of Polish in Kraków (for half a year in 1963) recalls that Wojaczek bought a two volume edition of Norwid published by PIW (most probably the edition from 1956 edited by Jastrun and Gomulicki) and carried it with him for a long time."He loved [...] the poem by Norwid [...] ('cedar is born not in gardens but in deserts' [...]). He was also moved by "Bema pamięci żałobny rapsod" ("Funeral Rhapsody in Memory of Bem") [...] we could talk for an hour or two about one line from Norwid! It perhaps sounds incredulous, but we were really into such par-excellence technical discussions" said Kronhold. (RWKB, 178).

Yes, it all fits-Bogusław Kierc in the latest biography of Wojaczek quotes a very early poem (from the manuscript, the notebook which he kept in 1964 "drzewo" ("a tree") with a motto:"cedar is born not in gardens but in deserts". ${ }^{5}$ This is probably the first trace of Norwid in Wojaczek's poetry; intertexts with Norwid's texts are mixed, as Kierc showed, with the dominant inspirations coming from the poem "Der Schauende" by Rainer Maria Rilke. Wojaczek returns, very discreetly, to Norwid's epigraph in two final lines connected by an enjambment:

3

anioł jest tylko zaprzeczeniem czasu

teraźniejszego i gnijącym cieniem

pałaców złotych i pustych szałasów

chwil spopielonych anioł ostrzeżeniem

4

jest rodzi cię z popiołu

puszczy spalonej dym to drzewo nowe

${ }^{5}$ B. Kierc, Rafał Wojaczek. Prawdziwe życie bohatera, Warszawa 2007, 172. 
które budować chce pióropusz aniołów umarłych człowiek. ${ }^{6}$

It seems that Kronhold, by calling his conversations with Wojaczek about Norwid's texts 'technical', pointed casually to the stylistic properties of Wojaczek's poems, because a stubborn drilling of individual lines would be transformed into poetic language, which was later accurately described by Romuald Cudak:

The lyric poems of Wojaczek are full of borrowings, which might be read either as conscious allusions, or as reminiscences. Most often these are motifs in the form of quotations and hidden quotations. However, they are rarely placed in lyric monologues of poems, and usually are placed in titles and in opening mottos. Wojaczek usually reworks the chosen formulae in his poems. Very often they are the backbones of these poems' constructions. In this way, a quotation used becomes the cornerstone of a new text. It is both an inspiration and a source of polemics and supplements; of a new or more radical reading. ${ }^{7}$

\footnotetext{
6 Ibid., 174. "An angel is only a contradiction of time(tense)/present and a rotting shadow/of golden palaces and empty sheds/Of moments turned into ashes an angel a warning/Is, he gives birth to you out of ashes of a forest/burnt smoke is a new tree which/wants to build plume of angels/dead a man."

7 R. Cudak, Inne bajki. W kręgu liryki Rafała Wojaczka, Katowice 2004, 192. Cudak, on the one hand, suggest that this way of referring to Norwid's poetry in Wojaczek's writings might be the result of the specific 'anxiety of influence', and therefore Harold Bloom's considerations could constitute a method to read Wojaczek's lyric poetry (unfortunately Cudak does not explain why it is exactly Norwid's reception which should be analysed with the tools of Harold Bloom), while on the other hand he claims (which I also find hard to agree with) that "the 196os was the period of revealing Norwid's writings to the general literary audience and a lively interest of it shown by [Polish] poets. Clear traces of Norwid's presence are also seen in the poetry of Stanisław Grochowiak, which Wojaczek was reading.".(See ibid., 193, 234). An interest in Norwid was certainly a generational feature of Generation '68. In this period Barańczak wrote his "Sonety łamane" ("Broken Sonnets") from his first volume Korekta twarzy (Facial Correction), clearly influenced by Norwid. A bit later Norwid was referred to, among others, by: Ryszard Krynicki and Adam Zagajewski, but I would hesitate to claim that a generational affinity in the case of Wojaczek had an influence on the poetic affinity.
} 
A. JARZYNA, "WOJACZEK: "NORWID SAYS HELLO..."

Such a way of communicating with Norwid's poetry will become one of the most characteristic features of his reception. Cudak's observations could be applied to all the poems I am going to interpret in this paper. Cudak, in his book about Wojaczek's lyric poetry, writes extensively about references to Romantic tradition, ${ }^{8}$ which he sees mostly in consecutive avatars of Wojaczek's volume of poetry Inna bajka (A Different Story), pointing also at fields of Wojaczek's inspiration by Norwid in all of his works. Cudak considers Wojaczek's relations with Norwid, although he does not deal with them in detail, as non-singular and multi-layered. "Norwid belonged to the most important poets of Wojaczek's canon."

Wojaczek's relations with Polish Romantic literature are particularly interesting with the poetry of Cyprian Kamil Norwid. The dialogue which exists in Wojaczek's poems with this poetry is based on overt allusions and reminiscences of Norwid's texts in the forms of quotations, allusions and stylization.[...]

Borrowings in the areas of the worldview and applied artistic categories are also obvious. After all, one of the foundations of Wojaczek's irony is the ironic use of Norwid's 'conceits'. Similar ties could be argued in the case of Wojaczek's lively interest in language as a material of poems and the foundation of poetic semantics. ${ }^{10}$

Lately it was Andrzej Niewiadomski who stressed the importance of the influence of Norwid on Wojaczek in an inspiring sketch "Wojaczek: nieuchwytna cielesność, nieuchwytne ciało poezji" ("Wojaczek: Intangible Corporeality, Intangible Body of Poetry"), where he too referred to Wojaczek's readings of Rimbaud, Miłosz

8 This theme has been dealt with, among others, by:B. Kaniewska, A. Legeżyńska, P. Śliwiński, Trudny romantyzm Rafała Wojaczka, in Literatura polska XX wieku, Poznań 2005, 259-269; A. Urbaniak, Poeta zbuntowany. O romantycznych inspiracjach Rafała Wojaczka, „Kresy” 2007, no. 4.

9 B. Kierc, op. cit., 169.

10 R. Cudak, op. cit.,. 232-233. 
and Norwid. ${ }^{11}$ Niewiadomski asked about the cohesion of Wojaczek's meta-poetic project, in order to state that his point of arrival turned out to be "a strategy of colliding discourses of modern poetry". (AN, $87)$.

Niewiadomski writes about the beginning of Pieśn czwarta Senatorium (Canto IV Senatorium) (1969), a posthumously published long poem in prose, in the context of Wojaczek's fascination with Norwid, although the reseracherseems not to see that in the very first sentence the protagonist of the poem, Piotr Sobecki, ${ }^{12}$ (regarded as Wojaczek's alter ego) defines his attitude to poetry by answering the question Norwid asked in the short text in prose Bransoletka (The Bracelet) "Jestże się poetą, czyli raczej tylko bywa się?-" ("Are you a poet, or do you only happen to be a poet?") (PW, 6, 38):

Verily I say unto thee, that, you are a poet. You are a poet through your life. While you happen to be a scribe, or a literary wannabe. You happen to be one when you have no strength to bear the weight of life. Then you run away to a garden, artificially fenced off and grow gloomy flowers on a tidy flower bed. It is quite okay if this process is accompanied by irony. But usually a gardener assumes that a flower so carefully looked after by him is as beautiful as a blue rose. In cases

\footnotetext{
11 A. Niewiadomski, Wojaczek: nieuchwytna cielesność, nieuchwytne ciało poezji, „Kresy” 2007, no. 4, 88 (Herafter: AN). It is known that Wojaczek was a voracious reader. When he was in secondary school he recited by heart whole pages of Doctor Faustus. Jerzy Kronhold describes the impression Wojaczek was making on his colleagues, the first year students of the Department of Polish Philology, Aleksander Fiut was one of them, "to say that Wojaczek read intensively is to say nothing. Rafał read terribly much. We simple hated this reading, it was a kind of 'total reading'(RWKB, 174). He read mostly "huge quantities of poetry" (apart from Norwid also, among others, Rilke, Rimbaud, Przyboś) and Dostoyevsky's Demons or Brothers Karamazov, he would sit down to reading around four in the afternoon and finished around ten"-adds Kronhold.

12 The protagonist of "A Letter to the Queen of Poland" (another short story by Wojaczek) also reads Norwid. He explains his behaviour, which is incomprehensible to these around him with Norwid's words from Vade-meum („Nadlogiczne niekoniecznie bywa przeciwlogicznym" ("What is above logic is not necessarily against logic") (WUZ, 309))
} 
A. JARZYNA, "WOJACZEK: "NORWID SAYS HELLO..."

of more advanced madness, such a gardener totally loses his grip on reality. He has grown a rose!![...]

This clatter, this noise, this ceaseless shouting, loud announcement about invention your own way. Poor them, they cannot muster a moment of silence. They cannot because they would instantly listen to their void booming with their stomach rumbles and would die because of this noise. ${ }^{13}$

It is a different issue if the protagonist of Sanatorium really is identical with the author and if his words could be attributed to Wojaczek, and regard it, as Niewiadomski does, as the comment on himself. He reads this fragment in the following way:

a project of poetry integrally connected with life [...], in which using and creating conventions might only serve as a means, not a goal [...] and in which 'artificiality' (symbolized by a 'blue rose') is allowed only if an author treats it symbolically, with a distance, being fully aware of its provisional character. The opposite pole (also opposite to the form which is not treated with irony) is occupied by silence, the positive role of which has not been precisely described here. This fragment constitutes an approach to poetry grounded in the set of 'competing' categories: life-means/artificiality/roseirony. silence. This approach, however, is 'borrowed', Wojaczek's debt to the concepts of avant-garde as well as post-avant-garde concepts of poetic language (Przyboś), and also to Różewicz and Norwid, is undeniable. (AN, 70-71).

As far as this interpretation is concerned, I would like to add to the theme of reception: apart from the quotation from The Bracelet, which usually functions as a general aphorism, quite often without any connection with Norwid (for example, Karpowicz saw in this phrase a polemic with Przyboś and his statement "Poetą się nie jest, poetą się bywa" ("You are not a poet, you happen to be a poet") (WUZ, 15). This brings associations with Czarne kwiaty (Black Flowers), in which Norwid stated: "a writer tries to avoid the style out of respect

13 . Wojaczek, Utwory zebrane, intro [czy nie powinno być raczej: foreword?]. T. Karpowicz, ed. by B. Kierc, Wrocław 1976, . 258 (Hereafter: WUZ). 
for the thing described, and complete and gripping in itself" (PW, 6, 175). And a bit later: "However, there are such passages in the book of life and knowledge, for which there do not exist formulae of style" (PW, 6, 175). Meta-comments of Norwid are, according to Piotr Śniedziewski "nothing else, but a manifesto telling literature to stop being literature. ${ }^{14}$ Questioning the style, Norwid's lack of trust with words meet with Wojaczek's conviction that not everything could be said, and that is why a true poet confronted by "an ordinary tree, ordinary grass, an ordinary dandelion in grass (as in Sanatorium (WUZ, 258)), will choose silence. Norwid's context only strengthens associations of this fragment of Santarorium with "Róża" ("A Rose"), a sonnet by Wojaczek which was not published in any of his volumes of poetry, the motto of which is a quotation (not quite precise) from "A Dorio ad Phrygium" by Norwid: "She was called Rose/-Was she Called It?"

Jakby Ciebie nie było wcale, w ścisłym czasie

Mojego serca byłaś nielegalną nocą;

Ciało śniegu na jego biegunie północnym,

Dowolne gniazdko plotłaś sobie z sypkich włosów

Westchnienia. Nie słyszałem Twojego imienia

W żadnej burzy od wschodu ani od zachodu

- siebie tylko słyszałem w zaślinionym trwogą

Kaszlu mowy, chcącego wymówić to słowo.

Ale widać w nieznanej gwieździe Twoje imię Różowe spało; lecz, choć poróżniony z nim,

Ślepo wierzę, że będzie we mnie pełnia krwi

Taka, jakby blask zgasłej Ziemi, co przez Kosmos

Poleci. Wtedy wytchnę poemat dorosły:

Milczenie, co Cię Różą nazwie już prawdziwie. ${ }^{15}$

\footnotetext{
${ }_{14}$ P. Śniedziewski, Poeta „skąpy w mowie”.O milczeniu u Norwida, „Pamiętnik Literacki" 2007, (4) 38.

15 R. Wojaczek, Wiersze zebrane, ed. by B. Kierc, Wrocław 2006, 276 (Hereafter: WZ). "As if You were not at all, in the strict time/You were an illegal night of my
} 
A rose is never only a flower, never only a woman, it is a pseudonym of what is inexpressible - a flower and a woman, it draws a horizon of poetry's possibilities. ${ }^{16}$

"A Rose" by Wojaczek is an auto-thematic love poem. It asks how to name in order to be closer. Aleksandra Okopień-Sławińska wrote about Norwid's words used in the motto to the poem that "a tone of doubt, or a conventional giving of a name is an act of deep meaning. It establishes a real relationship between a person and the word which names him/her" ${ }^{17}$ The phrase: "She was called Rose/—Was she Called It?" (PW, 3, 321) precedes the best known fragment of this unfinished long digressive poem, which most readers take for a separate poem "Jak.." ("How...") (Juliusz W. Gomulicki regarded it as the lost part LIV of Vade-mecum). This is one of most mysterious poems by Norwid, in which writing about beauty is similar to what the poet is trying to say-beauty disappears when one gets close to it. As OkopieńSławińska wrote, each line of this lyric poem is "an attempt to find a verbal equivalent for the experience which is finally not revealed." 18

"A Rose" could also be treated as an answer to Norwid's motto. In this poem we have an identical situation as in "How..." (finished

\footnotetext{
heart;/A body of snow on its Northern Pole/You would make any small nest with your crumbly hair/Of a sigh. I have not heard Your name/In any thunderstorm from east to west/-I only heard myself in saliva smeared terror of a cough/Of speech, wanting to utter this word./But on an unknown star one can see Your name/Rosy sleeping, but although disunited with him,/I blindly believe that the full blood will be in me/Such, as if the glare of extinguished Earth, which through Cosmos/Will fly. Then I will gasp a mature long poem:/Silence, which calls you Rose will call it truly."

16 A motif of a rose (also of a rose and a star, because they often appear together) in Wojaczek's poetry, because of various meanings analysed many times (among others by Karpowicz, Barańczak, Niewiadomski) still waits for a separate sketch. It may create associations with the poetry of Rilke; it is in his sonnet "A Rose" where Wojaczek, just as Rilke in "Inside a Rose", tries to "express the inexpressible".

17 . A. Okopień-Sławińska, Semantyczna strategia poetyckiego zamilczenia (Przypadek „Jak...” Cypriana Norwida), „Teksty Drugie”

200o, no. 5, 41.

18 See A. Okopień-Sławińska, 33.
} 
with the line: "but I will say nothing because I am so sad"), a choice of silence, a gesture of rejecting the validity of the text written earlier in the poem, draws the attention to the very text. But, whereas Norwid, from the first lines, breaks the convention of description, the convention of the lover's confession, Wojaczek decides on the use of the most fixed (and overused) convention-nothing more typical than a sonnet entitled "A Rose"- and in this way he creates an effect of unfulfilled expectations. Norwid's poem is brilliant "instead" (also instead of silence). This is a sequence of pictures, unfulfilled similes, which take readers' attention from the subject of the description. In Wojaczek's poem this sequence may be recalled by one opening simile-apostrophe "As if You were not here at all". Because of this, the whole of the first stanza turns into a chain of periphrases of intangible shape ("illegal night", "body of snow") connected by associations with "How..", because even in the last line of the poem" "You would make any small nest with your crumbly hair") there exists a remote similarity to Norwid's poem ("As if a person standing on a porch/Had hair braided with the remote moon."). From this moment the mood of the poem changes, the helplessness of the lyric 'I' grows, and we start concentrating on him. His words containing all that is unequivocal in a lover's confession; too conscious of itself.

The further part of the poem-opened with the enjambmenther sigh, is closed with a gasp ("gasp a mature long poem"), neither a sigh nor a gasp will become a voice-it is an attempt to be silent on the cosmic scale "(the full blood will be in me/Such, as if the glare of extinguished Earth, which through Cosmos/Will fly") Even though language ("cough of speech") cannot cope with the task of naming Rose, her name, encrypted in a pseudo-etymological way, resonates in the poem itself, twice in one verse, in the paraphrase "imie różowe" ("rosy name"), and paradoxically in "różnicą" ("difference") ("poróżniony z nim") ("quarrelling with her").

Niewiadomski, who ends his sketch with the analysis of "A Rose", sees the connections with Norwid differently-he claims that piling up in the poem of declared authenticity reduces irony which allows a contemporary poet to move "beyond the parenthesis in which 
A. JARZYNA, "WOJACZEK: "NORWID SAYS HELLO..."

Norwid puts poetic activities". (AN, 86) Whereas I tried to show that different conclusions could be drawn from reading of this poem in the context of words, which in "A Dorio ad Phrygium" are placed just after the motto-then it becomes clear that both poets rely on a similar strategy.

Niewiadomski later concentrates on functions which Wojaczek ascribes to silence. He tries to convey them in the context of the metapoetic project of Wojaczek - as he understands it-the project which was based on moving beyond "literary schemata" and arriving at his own formula of poetry. Niewiadomski wrote that in "A Rose"

Poetry which exists as clear, its own voice, is not named. Because Wojaczek-unlike Miłosz-cannot express the will of "being pure perception with no name". Moreover, he suffers from the malady of aestheticism (this aestheticism, however, is marred by a nostalgic attitude to the body) and all the time he tries to "name". These desperate attempts lead to the following statement: "silence will be pronounced as truth". (AN, 86-87)

Niewiadomoski sums up his interpretations in the following way:

Wojaczek tried to be a poet of miracles, assuming that silence could save the authenticity of the body entangled in metaphors, pseudonyms and symbols, while that silence at the same time may make it a part of some spiritual truth, a fragment of 'new' art. (AN, 87)

Niewiadomski also writes about Norwid's inspiration in relation to the poem "Dał się nabrać na język którego nie było" ("He Was Taken in by Language Which Was not There") opening the volume Którego nie było (Which Was not There). He is interested in Wojaczek's search for "the formula of poetry solving key dilemmas connected with its status in relation to reality" (AN, 73). In this context the reference to Norwid's prologue from Vade-mecum, in Ogólniki (Generalities) (Niewiadomski did not deal with it in his sketch) is equally interesting, and from the perspective of reception creates a bit less doubt. Generalities was written in the same year in which Sanatorium was written, and it was never published. It is true that 
here, similarly to the poem "He Was Taken in by Language Which Was not There", references to Norwid should be discussed in the mode of presumptions and intuition, not of certainty.

1

Światło dzienne, co mieszka w zimnej kości świtu,

Miewa niekiedy adres tymczasowy w kości

Ponurego przestępcy, którym jestem ja.

2

Chleb powszedni, który nie lęka się dzielenia,

Głodu, ognia; którego nie można rozstrzelać,

Przecież przez żołądkowy trawiony jest kwas.

3

Dobra matka, co wstydzi się rosłego syna,

Kultywując kurestwo po to, by zatrzymać

Młodość, wszak wreszcie musi potknąć się o śmierć.

4

Miła ojczyzna, nawet nie mit, lecz domena

Zza krat każdego nieba, bram wszelkiego piekła,

Niespodziewanie we śnie odpomina się.

5

Uczciwe społeczeństwo, które mnie wyklucza,

Nawet nie wie, jak wielu głosów w sobie słucham,

Prawdziwy naród mając u siebie we krwi.

6

Słowo polskie, plugawa gazetowa mowa,

Jeśli cenzurze wymknąć się niekiedy zdoła,

Nieregulaminowo i tak niewdzięcznie brzmi.

$(\mathrm{WZ}, 245)^{19}$

19 "Daylight which lives in the cold bone of a dawn,/Sometimes has a provisional address in the bone/Of a morose criminal, whom I am.//Daily bread which is not afraid of dividing,/Hunger, fire which cannot be shot,/After all is dissolved by gastric acid.//A good mother who is afraid of a stalwart son,/Cultivating whoring in order to prolong/Youth, must trip over death.//Nice homeland, not even myth but domain/Behind the bars of each heaven's gate of any hell,/Unexpectedly in sleep gets unremembered.//Honest society which excludes me,/Doesn't even know how 
A. JARZYNA, "WOJACZEK: "NORWID SAYS HELLO..."

Tadeusz Pióro interprets this poem, particularly its last lines in the context of Norwid's phrase (from the poem "Za wstęp" ["Instead of Introduction"] included in Generalities). "Granting objects proper names!" (PW, 2, 13), which, as Pióro claims-Wojaczek recalls in order "to receive contemporary conditions in which such poetics could function" 20 in order to show "the condition [...] of someone writing in the language ruthlessly subjected to ideology by those who sanction the transition from private 'voice' to public 'speech"'. ${ }^{21}$ In my opinion, the acquisition of the general rule which Norwid gives in the poetic introduction to Vade-mecum is more important than this reminiscence:

1

When like a butterfly the Artist-mind

In Spring of life inhales its air.

It can but say:

I The earth - is round - it is a sphere'

2

But when autumnal shivers Shake the trees and kill the flowers,

It must elaborate:

'Though somewhat-flattened - at the poles

3

Amid the varied charms Of Eloquence and Rhyme One-endures above the rest:

$* * * * * * * *$

Granting objects proper names. ${ }^{22}$

many voices I listen to myself,/True nation having in its blood.//Polish words, filthy journalistic speech,/If sometimes manages to dodge censorship,/Not orderly and ungraciously sounds."

20 T. Pióro, Posłowie in Który jest Rafał Wojaczek w oczach przyjaciót, krytyków $i$ badaczy, ed. by R. Cudak, M. Melecki, Katowice 2001, 175 (Hereafter: KJ).

${ }^{21}$ Ibidem.

${ }^{22}$ Cyprian Kamil Norwid, Selected Poems, transl. Adam Czerniawski, Anvil Press Poetry, London, 2004, 57. 
Each of Wojaczek's lines from Generalities opens a positive idea-a symbol (daylight, mother, homeland, society, Polish word), each is supplemented by an unexpected, ambivalent context ("Bread [...]/After all is dissolved by gastric acid). It could be claimed that each is connected, in miniature, to the structure of the first two lines of Norwid's poem, in which an author postulates that poetry should reveal the ambiguity of seemingly cohesive reality.

Therefore, it is not only silence as Norwid's sole strategy in Wojaczek's poems. Norwidian is also-as Karpowicz put it-striving to "tell the truth to the very end by the language of poetry free to the very end". (WUZ, 11)

It is difficult to find the key to Wojaczek's reception of Norwid. It is true that Romuald Cudak presented an interesting claim and made an almost complete catalogue of references which confirm it, but because he did not interpret individual poems, he lost sight of what is most interesting-nuances. Niewiadomski, on the other hand, wrote about only one area of Norwid's influences, while we have several poems of Wojaczek in which these references were made in divergent ways. I will start from erotic poems-perhaps most unusual one in Wojaczek's poetry-and a double reference to Milczenie (Silence), a late text in prose (1882) by Norwid.

The poem "Okno" ("The Window") comes from Sezon (A Season)

I

Głowa jest zimna Gwiazda chłodzi przełyk

tylko okno płonie we krwi

Lubię być obcy pod Twoim oknem

jakby na pół urodzony.

Myślę o Twoim brzuchu

ręce chowam za siebie

Teraz sprawdzam rysy swojej twarzy

jakbym je ustalał

z Twoimi wargami.

Śmierć jest obojnakiem. 
A. JARZYNA, "WOJACZEK: "NORWID SAYS HELLO..."

\section{II}

Gwiazda przecieka do stóp I tak muszę iść

twarz pali a podbrzusze jak otwarte okno

Kiedy śpisz wiesz o czym ja myślę

Lecz czy śpiącą można zbudzić grzecznie

$(\mathrm{WZ}, 28)^{23}$

The poem "The Window" was composed, as we can learn from the journal written for Teresa Ziomber, between 12 August and 16 August:

I have been finishing the poem "The Window" over the last night and whole day.

(RWKB, 155)

This is the first note about this poem. Four days later, on 12 August, Wojaczek wrote:

I think that I have finally completed "The Window". I have been working on it for five days. This is different than anything else I have written for you (added: no, this is not quite like it, not yet). I know, Teresa, not yet, I have done it slightly different; these are details, but important-of how to read (Difficult).

Form. Form must be the only one, as a dress for you. As Your body. (RWKB, 159)

Why is this poem generally regarded as so ground-breaking? Wojaczek, as if sensed that in his poetry some new things started happening, he was aware of his poetic search for form. It is meaningful that he did not write "The Window" in his journal For Teresa (unlike

23 "A Head is cool A star cools the throat/Only the window is burning in blood/I like to be a stranger/Under your window/As if half born/I am thinking of Your belly hands/I hide behind me/Now I am checking the contours of my face/ As if I was defining them/With your lips./Death is hermaphroditic.//The star is soaking to the feet/And I have to go anyway face/is burning and stomach as an open window/When you sleep you know what I am thinking about/But can a sleeping woman be woken up gently." 
all the other texts on which he was working and to which he did not return later and did not publish), as if he, from the beginning, wanted to give this poem a larger audience; before it appeared in the volume of his poetry it had been published in Odra 1/1967. And there is also the thing most crucial from my perspective: this time Wojaczek did not reveal, as was the case with the poem "You Are Older", that he was inspired by Norwid. Why?

It is certain that even what he wrote in the meantime-on 14 August-can somehow explain the insertion into the poem of the quotation from Norwid:

Dreams-whey are You not here to wake me.

(RWKB, 157)

Practically the whole of this journal seems to be oneiric; it was written mostly at nights ("I can't sleep-Is it You that I owe this insomnia to" (RWKB, 158)). Sleep (a motif which in Wojaczek's poem is so important that a separate sketch on it would be a good idea) is also-as Andrzej Niewiadomski observed-one of crucial features of his poetry (AN, 72) and 'sleep(less) erotic poems' (as I have decided to call them) belong to a separate family of Wojaczek's poems (Including: "Która zmęczona śpi" ("She Who Sleeps Tired") or "Umiem być ciszą" ("I Can Be Silence")). They are very lyrical and dense. Norwid started his "Milczenie" ("Silence") with these words: "can a man by woken up gently? [...]"(PW, 6, 221). Wojaczek not only changed the grammatical gender (from 'he' to 'she'), but, deeply moved by this phrase, he created a love context for it. Or-and I think that this is a permissible interpretation-for each radical erotic poem he found a coda not from this world, not from this language.

Norwid's waking of a sleeping man is metaphorical. It describes a cognitive situation: just as you cannot introduce a new idea or a new invention without resistance-claims Norwid-so you cannot wake up a sleeping person gently:

even if we were to wake him up with the fall on the face of the lightest leaf of a rose, it would still be very exquisite and very poetic, but it 
A. JARZYNA, "WOJACZEK: "NORWID SAYS HELLO..."

would not be gently, because, after all, you have to break his dreaming thoughts and to break it at once, not gradually, but in one movement transferring into different reality. (PW, 6, 221).

In this way Norwid announces that he is going to deal with problems so far not dealt with. In his treatise he described the grammatical, philosophical and existential character of silence. According to Piotr Śniedziowski, "the essay became [...] a search for meanings, a game, dramatic at times, with what cannot be expressed, but which usually determines the character of human existence." 24

But is it certain that Wojaczek is removed a long way from the intricacies of Norwid's text and uses only the phrase, which, after all, he could have remembered from the text he had only scanned, but not read? While the problem of silence, as Norwid presents it, does not appear in the poem, it is important in the quoted fragment from the first paragraph of the essay.

She (lyric 'You") from "The Window" is in the similar situation to Norwid's sleeping man: awaiting awakening. He (lyric 'I' of the poem) only maturing ("half born") confronts himself with the one who is the object of desire. ("I am thinking of Your belly hands/I hide behind me") and everything is taking place under her window which ("is burning in blood"). The intrusion of death (which is "hermaphroditic") in the form of an individual line, an exception in this part of the poem, where all the other lines are grouped in twos and threes-abolishes all differences; it is impossible to be hermaphroditic in love. From the sleep of death there is no awakening, particularly no erotic awakening. The poet cuts the poem into two with this remorseless line (a warning against waiting for too long?).

In the second part of the poem there is a return from the lovers' non-meeting, and even more eagerness of the lovers' meeting, the same one to which she still only gets ready for. The lines "I am thinking of Your belly hands/I hide behind me" and "And I have to go anyway face/is burning and stomach as an open window" are symmetrical. Her waiting is just like the opening and closing of the window; it is not

24 P. Śniedziewski, op. cit., 22. 
a ceaseless (and sometimes even more ceaseless) readiness of the man. "She" in Wojaczek's poem turns out to be a mysterious creature, who lives differently than the man. "When you sleep you know what I am thinking about." She understands very well his shy, boyish rather than manly-wistful and impatient-waiting; maybe man's waiting is always somewhat boyish? At the end of the poem in a Norwidian question, but different from the one in Silence, the rhetorical one (To her or to himself?), we can hear the drama of his lonelinessof the loneliness of the lyric 'I', of his erotic lack of fulfilment and her-'sleeping', wise intuition to postpone the lovers' communion, to prolong what is uncertain.

Wojaczek-in whose poetry, as Tomasz Kunz put it, "subjective transformation" 25 occurred (his last volume consists exclusively of poems written in the female grammatical gender, is a different variant than "A Rose" of expressing inexpressible) - finds a transition from male 'I' to female 'I' also in Norwid's words. Wojaczek continued the unfinished story from "The Window" several years later in the poem "Czy śpiącą można zbudzić grzecznie" ("Can a Sleeping Woman Be Woken up Gently"), which comes from this final, posthumously published volume (1972) entitled Którego nie było (Which Was not There):26

\footnotetext{
25 Tomasz Kunz-I am recalling here one of the key arguments most often used by Wojaczak's researchers-understands this change of subject in Wojaczek's poetry as a result of his planned metamorphosis of his not perfect protagonist, the project to create textually a new person. "Trans-sexual mutation, a sex changing 'operation' was performed in Wojaczek's poetry only linguistically and was the end of the process, which was deemed to purge works from all traces of the presence of accidental (therefore, also determined by sex) authorial 'I'”.T. Kunz, Liryka Rafała Wojaczka: przemiany podmiotu poetyckiego in KJ, 245. Similarly: :J. Łukasiewicz, Liryka Rafała Wojaczka, in KJ, 162-172.

${ }^{26}$ Chronologically, between "The Window" and "Can a Sleeping Woman Be Woken up Gently" we have another poem entitled "Okno" ("The Window") with the date 17 July 1968. It begins with the words: „Natchniony dziś przez pamięć moich pierwszych wierszy / Z których każdy jest skrzepłą już kroplą krwi Gwiazdą"("Inspired today by the memory of my first poems/Of which each of them is now a coagulated drop of blood a Star") (WZ, 156). It seems that Wojaczek
} 
Sen zgęstniał rtęć opadła na dno ciała krew

Odpłynęła z twarzy

I już gołymi dłońmi odgarniałam śnieg

Który wargi parzył

Strach zmroził lecz nie straszyć lecz właśnie jął

Radość sobą karmić

Chociaż było nieomalże niestrawne to

Smakowanie gwiazdy

Krzak trzewi się spopielił by szczęśliwy ból

Krzykiem wyrósł z krtani

Kto jak nie Ty potrafił obudzić mnie znów

Pocałunkiem takim ${ }^{27}$

This time, the question "Can a sleeping woman be woken up gently" belongs more to the author of "The Window" than to the author of Silence. It is placed in the title and opens an answer to the sleepingwoken up woman (or maybe the dreaming-woken up woman). Because it is the sleeping-woken up woman who speaks, the unusual state of the focus of the language at the threshold of reality and sleep diffuses the sharp contours of her utterance. There is not a single punctuation mark in this poem, only enjambments regulate the places for taking breath, connecting pairs of lines, the long ones with the short ones, broken up in a caesura (12-6-12-6-Norwid wrote

refers to his earlier poem with the same title, although in this poem he gives up the reference to Norwid. In any case, this poem - to a certain extent auto-thematicis clearly different from the erotic poems joined by the quotation from Silence. It is interesting that it is in this poem and not in any of the poems discussed by me here, that Tomasz Kunz sees allusions to Norwid. See T. Kunz, op. cit.,. 243.

27 "Sleep got denser mercury sank to the bottom of the body blood/Flowed away from the face/And I was sweeping aside with bare hands snow/Which burnt lips/ Terror froze but not terrorizing it started/To feed joy with itself/Although it was almost indigestible this/Tasting of a star/A bush of guts burnt to ashes so that happy pain/With a shout grew out of the throat/Who, if not You, could wake me again/ With such a kiss." 
poems built according to this scheme, for example, the lyric poem [inc] [Ty mnie do pieśni pokornej nie wołaj] ([You do not call me to a humble folk song]) which was known to Wojaczek. In the kiss and in the act of love you need to synchronize breaths (and moments of breathlessness) and so two bodies get synchronized. Both-a kiss and an act of love-are penetrations. Both are, as "she" and "he" from "The Window" suspected, not-gentle, so the less punctuation in them, the better.

The experience is also a confession of the joyful fear of lovers' closeness. Oxymora testify to what is unusual in it: so we have the burning of lips with snow, "happy pain" (here the oxymoron is the result of the erotic union of words, with the association including paronomasia of "krzak trzewi" (a bush of guts) with "krzyk" (shout)). The intimacy of the experience is saved by metaphors. They also express the surprise of the intensity of bliss, which can be either burning or freezing (because-as in love-there is no place here for middle ground, for tepidity). Similarly, in "The Window" ("a head is cool", "the window burning in blood", "the face is burning"). Also, "smakowanie gwiazdy" ("tasting of a star") in "Can a Sleeping Woman by Woken up Gently", inter alia, related with metaphorical expressions in "The Window": "a star cools the throat", "soaking to the feet", as if this star (one of the most often repeated symbols in Wojaczek's poetry) circulated between poems, between loneliness and closeness. Stanisław Barańczak wrote that in Wojaczek's poetry "a star is a symbol of all these values which help to overcome loneliness [..], and at the same time this is a type of transcendence most difficult to attain, the object most remote and most perfectly lonely". ${ }^{28}$

The division into stanzas was left in this poem not only in order to take a respite, between the parts, from pictures recorded at the limit of imagination, but also to understand consistency in the transformation from deep sleep to violent shout, to cover the description of perfectly measured bliss: from the touch of the surface of lips, through tasting, shallow at first, to collapsing

${ }^{28}$ S. Barańczak, Rafał Wojaczek. Metafizyka zagrożenia, in KJ, 100. 
into each other to some unbelievable depth of throats; this gradation makes a kiss into the synecdoche of an act of love. And when at the end, in the two final lines, which come as rest after love's fulfilment, it is her-the female experience of sexual proximity which changes into a portrait of its originator. ("Who, if not You, could wake me again/ With such a kiss"), it becomes more probable that the lyric ' $\mathrm{I}$ ' is also female; also (primarily?) because, the proper lyric 'I' wanted to be the lyric 'You'.'

The dominant theme of the first text was lack of fulfilment, impatient longing, closer to Norwid's erotic poems (but in "The Window" clearly of bodily character). As far as the second text is concerned, it is only in the last line that we learn for sure that it is an analogon of a kiss. Together they form, written in one Norwidian sentence, a micro-story of love, most similar to fairy tales (who does not remember the story of the Sleeping Beauty?) of all stories which Wojaczek experienced. These are special poems, not only because they were published during Wojaczek's life, unlike most of his poems related to Norwid, but mostly because such reticence rarely happened in Wojaczek's love poems. ${ }^{30}$ Norwid turns out to be a patron of subtle erotic poems,

${ }^{29}$ The metamorphosis of the subject of Wojaczek's poems is interpreted in a similar way by Jacek Łukasiewicz and Tomasz Kunz. Łukaszewicz stresses that from the volume An Unfinished Crusade onwards, in Wojaczek's poetry there appears another, better 'I', which gets involved in a conflict with the empirical 'I': "Rafał Wojaczek" starts functioning in this poem as their main protagonist. According to Łukaszewicz, the introduction of the female ' $I$ ' is an act of killing of the empirical 'I'T. Kunz, op. cit., 235-245.

${ }^{30}$ Tymoteusz Karpowicz, in an extensive introduction (enitled "Sezon na ziemi" ("A Season on the Earth") to Wojaczek's Utwory zebrane (Collected Poems), although he did not point to Norwid's references, wrote that despite the tendency in Wojaczek's poems to limit love to sexual desire, in some of his erotic poems (for example, in "Can a Sleeping Woman Be Woken up Gently") there appears: "the need for tenderness and ecstasy, illumination by love going being the physiology of the sexual act. There returns, and replaces pictures disregarding the dignity of women, the tone from The Song of Songs [...] A pimp is transformed into a priest, celebrating mass on the white altar of the female body. In the place of physiological sperm there appears the winter crop of the genre which is to bring salvation to the world from 
with piercing silence, similar to the ones Norwid had written himself, although the difference in language is enormous. Wojaczek uses the words of Norwid as poetically perfect; in this situation knowledge of the context did not really matter to him, but reading both these poems inclines one to refer them to the first paragraph of Silence. If only because the physical love union always opens new worlds, and awakenings after them are like epiphanies.

"Reszta krwi" ("The Rest of Blood") is a love poem in the manner of Norwid, although there is little erotic closeness in it. It is also known only from the posthumous publication of Wojaczek's lyrical poems in 1967, which could be read via "W Weronie" ("In Verona") as an interpretation of a story from Romeo and Juliet. Both poems deal with what happened after the epilogue of Shakespeare's drama. Wojaczek reverses the lyrical situation from poem VI from Vademecum - here someone external from the protagonists describes-but describes what? A tear falling on their graves or, is it as others have it, a stone? The contemporary poet gives voice to the tragic lovers, who from the cosmic perspective look at the Earth: "You see/this is the Earth/It looks as a star/At the bottom/tears"-in these opening lines there appears an echo of a Norwid's falling star- "tears from above the planet" which "soak graves" (PW, 2, 22). He asks: "My love, I don't know/what is shining over there, surely it must be/a ladybird", and she answers him in the final lines, again in a Norwidian way, that thanks to their deaths the metamorphosis of the world is in progress, redemption: "This is the rest of our blood/'which is shining through the globe."(WZ, 364)

I take the liberty to interpret "The Rest of Blood" (in a rather cursory way) mostly because of the relationship with the problem of sacrifice, as it is connected with the reception of Norwid in Wojaczek's poetry also in "Moja piosenka, (A.D. 1969)) ("My Song. (A.D. 1969)) and in "Vademecum"-other poems not published in

the cold which is encroaching from all directions:" (WUZ, 20-21). I would argue with such a strong dichotomy. After all Wojaczek finds tenderness inside a radical erotic poem. 
A. JARZYNA, "WOJACZEK: "NORWID SAYS HELLO..."

any of Wojaczek's books of poetry. The former might be, at first sight, expected to be connected with one of Norwid's "Moje piosenki" ("My Songs), the other, obviously, to be an allusion to the title poem of Vade-mecum (which is known as [inc.] "klaskaniem mając obrzękłe prawice"("the people's hands were swollen with applause"), "My Song (A.D. 1969)" is a paradoxical formula, the possessive pronoun and the date in the parentheses herald a personal poem, although reference to Norwid is clear. But the graphical shape of Wojaczek's "Vademecum" is even more complex. By removing the hyphen form Norwid's Vade-mecum, Wojaczek questions the suggestion of reference to Norwid, after all he used the version of this borrowed common word which functions in Polish. Intertextual signals in both of Wojaczek's poems turn out to be equally discrete, difficult to prove except for the titles. However, thematic affinities allow us to deal with these poems in the context of the influence. I will concentrate only on "My Song (A.D. 1969)" as Norwidian allusions are here more visible, and his interest in Norwid's "My Song [1]" was testified in a fascinating way also in other texts by Wojaczek:

Moje słowo, Twego słowa pogłos

Jakże wątły, przecież sprzymierzony

$\mathrm{Z}$ wiernym rymem, rytmem wspomożony,

Bywa czasem nie tylko ulotką.

Moja nędza, Twojej nędzy siostra

Młodsza, jeszcze jej sukienki nosi,

Lecz doprasza się - pilnie podnosi -

Ręki, która by do szczętu zwlokła.

Moja wina, Twojej winy krewna

Biedna, jednak gdy okruch splendoru

Połknie, wtedy biorąc się na sposób,

Sama sobie na krzyż składa drewna.

Moja wiara, Twojej wiary córka

- nie wiem czy głupia; imienia 
Nie przyzywa, milcząc się uśmiecha, Jakby tylko łaskotała włócznia...

$$
(\mathrm{WZ}, 282)^{31}
$$

These are words spoken before death. The person who utters them gets closer to Christ, maybe even identifies himself with him, which Wojaczek tries to show through semantics and the shape of the poem. In this sense "My Song" seems to be an obsession of the poet, which is poetically transformed. In an interview (from August 2006) included in the book Wojaczek wielokrotny (Multiple Wojaczek) Jacek Łukasiewicz says that just after the publication of his review of A Season ("Krew i gwiazda" ("Blood and a Star", Odra 12/1969) he received from Wojaczek his photograph with the letters INRI written on his forehead. ${ }^{32}$

A few months later-on 2 March 1969-Wojaczek wrote to his mother:

Soon we will have Easter-I hope it will be warm and good.

Resurrection of Jesus Christ, my alter ego - not so long ago I wrote a Christmas carol for his birthday, now, for the last month I have been writing his crucifixion. There is solace in the fact that everything which happens personally has a reference to a myth and is not accidental. Our Fate written with stars-you only have to learn to read it (RWKB, 110; emphasis- A. J.).

\footnotetext{
31 "My word, your word's reverberation/How weak although allied With/A faithful rhyme, helped with rhythm,/Sometimes is not only a pamphlet./My misery, your misery's sister/Younger, she still wears her dresses,/But she asks-urgently picks up/For a hand, which would totally take it off/My fault, your fault's cousin/Poor, but when a bit of splendour/Gulps, then, in an ingenious way/She on her own for the cross gathers wood./My faith, your faith's daughter/I don't know if she is stupid, the name/Doesn't utter, in silence he smiles/As if the spear only tickled."

${ }^{32}$ See S. Bereś, K. Batorowicz-Wołowiec, Wojaczek wielokrotny. Wspomnienia, relacje, świadectwa, Wrocław 2008, s 384 . Earlier

Łukasiewicz wrote that Wojaczek had sent such a photograph to friends while he was working on A Season, therefore before 1969. See. J.

Łukasiewicz, op. cit., 164.
} 
A. JARZYNA, "WOJACZEK: "NORWID SAYS HELLO..."

Even if intuition fails me and the emphasized fragment of the letter "now, for the last month I have been writing his crucifixion" does not refer to the poem "My Song (A.D. 1969)", the poem "The Cross" (which comes from the volume Nieskończona krucjata (An Unfinished Crusade), and which was unfortunately was not dated, perhaps the poet had this poem in mind in the journal) confirms Wojaczek's identification with Christ.

Tymoteusz Karpowicz (who was called 'The Master of the Polish Language' by Wojaczek in the dedication he wrote in An Unfinished Crusade) characterized the point of arrival of Wojaczek's rebellion:

His practised atheism ends up in a meeting with God, evangelical Christ. Christ-the model is there and now you have to kneel down. You cannot deny Wojaczek's longings for God, hidden deeply in his blasphemies, which are like exorcisms. The Christ he meets is a long way from bigotry[...] He appears as a tranquillizing force. $\mathrm{He}$, Wojaczek, a free mustang, lets this force put a bridle on his raving heart. This is a surprising result of crusades, directed also against God. (WUZ, 27).

Karpowicz, who knew Norwid's writings very well, in A Season on the Earth shows, very discretely, Wojaczek's relations with Norwid. It could even be stated that he avoids such associations, and while writing about "My Song (A.D. 1969)" he practically ignores them, as if his-reader's and interpreter's-premonition of the difference erased an obvious (after all stressed in the very title of the poem) suggestion of similarity. Norwid's figure of a poet-Christ is well known. Jacek Trznade $^{33}$ was one scholar who wrote about it (referring, first of all to Norwid's poem, important for Wojaczek-[inc. ["You do not call me to a humble folk song"]. He stressed the mythologization of the protagonist of these poems through references to the figure and crucifixion of Christ, but it was Karpowicz who was the first one to see that Norwid avoided a direct imitation of Jesus: "The act of confession is connected in Norwid's poetry with the notion of one's

${ }^{33}$ J. Trznadel, Czytanie Norwida. Próby, op. cit.,. 293-328. 
own cross, [...] one's own Golgota, and not with following behind the cross of Christ, that is following behind someone else's suffering and redemption." 34

Wojaczek's poem is in this respect similar, although the parallel structure of stanzas looks like an attempt to locate oneself in the story of the other (Christ). The lyric 'I' defines himself always as inferior to "word", "Misery", "guild", and it is only when the faith is referred to that the rule of analogy is broken ("the name/Doesn't utter, in silence he smiles/As if the spear only tickled. "). Awareness of the difference is hidden in ellipsis at the end of the last line, in silence, the protagonist frees himself from the formula accepted at the beginning of the poem-just as the author with each line frees himself from references to Norwid's $M y$ Songs. The wish of associations with Norwid returns unexpectedly, when we recall that he referred to the last words of Christ in the same way in the poem "Wczora-i-ja" ("Yesterday—and I") (1860), "I nie chcesz krzyknąć:«Eli... Eli...»czemu?" ("And You Don’t Want to Cry <Eli...Eli..>), Why? (PW, 1, 334). Of course, the key question is: Did Wojaczek know this poem? He might have remembered it, because it is included in the edition by Jastrun and Gomulicki, which he had bought while a student in Kraków. ${ }^{35}$ It is possible, however, that Wojaczek was not influenced at this point by "Yesterday-and I"

Although "My Song (A.D. 1969)" does not offer such evidence, it is certain that Wojaczek knew and appreciated "Moja piosnka [1] ("My Song [1]"). In the journal he kept during his stay in a psychiatric hospital in Wrocław (7-22 May 1965, he was diagnosed with psychopathic disorders and the threat of schizophrenia was suspected), on 14 May, without any comment, directly under his own poem (a kind of lyric

\footnotetext{
34 T. Karpowicz, Pielgrzym i jego veritas w zbiorze:Norwid bezdomny. W 180 rocznice urodzin poety, ed. by J. Kopciński, Warszawa 2002, 58. For example, in the letter to Joanna Kuczyńska from 1862 which ends in the statement in "parvenu de la Golgothe - un parvenumartyr!" Norwid wrote about an individual experience, different than Christ's experience at Golgota (PW, 9, 59-61).

35 See C. K. Norwid, Poezje, v. 1, ed. by M. Jastrun and J. W. Gomulicki, Warszawa 1956, 112.
} 
exercise, a strange confession of someone contemplating suicide)-he wrote down (this note is in ink-as the publisher explained-therefore it may have been written after he was released home, patients were allowed only pencils while in hospital) - probably from memory, as he made a mistake - the first lines from Norwid's poem:

Bad, bad, everywhere, always

The black thread weaves and worries

Behind me and before me and nearby.

$$
(\mathrm{WUZ}, 43)^{36}
$$

It is interesting that it was these very words which came to Wojaczek's mind while he was keeping (or editing) his hospital/s journal. They may be interpreted as an attempt to come to terms with the medical diagnosis ("Do psychopathic disorders necessarily lead to psychological degradation?" (WUZ, 43)) and depression? The reference to three subsequent lines ending this stanza („Ona w każdym oddechu, / Ona w każdym uśmiechu, / Ona we łzie, w modlitwie i w hymnie") ${ }^{37}$ (PW, 1, 65)) could also be seen in the first untitled poem from the cycle "Śmiertelny wiersz" ("A Deadly Poem") from the volume A Season. (It was written almost a year later than the journal's note, 12/13 July 1966):

Uspokój się, mój śnie, jej nie ma

Ale ona jest

aż serce ścisłe,

kryształ strachu

Ona jest, mój śnie

aż krew zbielała

Nie ma jej, ona w każdym płomyku

ostatnie serce,

śmiertelny wiersz

\footnotetext{
${ }^{36}$ Cyprian Kamil Norwid, Poems - Letters - Drawings, trans. by Jerzy Peterkiewicz, Carcanet, Manchester, 2000, 3.

37 "She is in every breath,/She is in every breath,/She is in tears, in prayer, in hymn."
} 
Nie ma jej, ona w każdym oddechu,

echo.

$$
(\mathrm{WZ}, 26)^{38}
$$

Both poets write about inevitability, the poetic figure of which is repetition-Wojaczek's poem seems to be a variation on several lines from Norwid (from the stanza which is also repeated in the poem, as the first and penultimate one), but a variation, in which a semantic shift in the directions of things finally happens. In "My Song [1]" "sheblack thread" one of two threads with which Parka's wove human fate, means unhappy days, Wojaczek's "she" is probably death (as the title of the cycle indicates).[inc.],,uspokój się mój śnie” ([calm down, my sleep]) is a poem written with phrases from sleep (his brother's death): long lines, as a steady breath during quiet sleep (it is in them that the phrase ("she is not here") are contrasted with the short ones, resembling shallow breathing, straight from a nightmare. The ending, with the quote from Norwid („ona w każdym oddechu”) is brilliant. Death in the shape of assonance is revealed as an echo in what is the most basic signal of life.

"My Song [1]" ends with the words: "Oh, I have played and sadder still am I"39; I believe that Wojaczek might have remembered them while writing, in 1970, "Ranny wiersz" ("A Wounded Poem"). If the case was, as Jerzy Kronhold claimed, that Wojaczek reached for Norwid "as if he was searching in this bank of quotation for an alibi for himself" ${ }^{\prime 40}$, then the important (most important?) words are quoted in the last stanza of "A Wounded Poem"

Jestem jednakowoż tak niezmiernie smutny

Że aż Bogu smutno jak to powiedział Norwid

Ale gdzie mi tam zachować królewskie milczenie

I oto oblicze niebios co przez szyby dnieje

\footnotetext{
38 "Calm down, my sleep, she is not here/But she is/As tight heart,/A crystal of fear/She is, my sleep/till blood went white./She is not here, she in each flame/ last heart,/a deadly poem/She is not here, she in each breath/echo".

${ }^{39}$ C.K. Norwid, Poems - Letters - Drawings, op. cit. 4

${ }^{40}$ Quoted in S. Bereś, K. Batorowicz-Wołowiec, op. cit.,. 164.
} 
A. JARZYNA, "WOJACZEK: "NORWID SAYS HELLO..."

Wyję, naprawdę wyję jak skopany pies

Nie mając na dodatek nawet tej tak marnej

Pewności czy skoro wyję, to żyję?

$$
(\mathrm{WZ}, 294)^{41}
$$

Wojaczek was referring here, very discretely, to Norwid's "Aerumnarum pelnus" (1850) and, primarily, to the last stanza of the poem [inc.] "do not call me to a humble folk song"

Deep in the heart when the cruel purple plaid

Is woven by the weaver of pain and cries,

The sad ones- but so sad that God is sad -

Have royal silences. ${ }^{42}$

It is significant that Wojaczek takes a poetic letter to Teofil Lenartowicz, with which Norwid, who was experiencing at that time writer's block (after the return from the USA), answered his friends prodding that he should return to writing. It is significant, particularly because Wojaczek recalled this fragment from Norwid first in the moving letter to Stanisław Chaciński (a writer from Wrocław and a close friend of his) written on 3 December 1967 from the prison in Wrocław: (He was sentenced to two months of imprisonment for aggressive behaviour in Klub Związków Twórczych i Dziennikarzy (Artists' and Journalists' Club)). I am quoting almost the whole text of this letter; Wojaczek in no other place testified to his reading of Norwid in such a way:

Your letter was very sad. As, sad, as man's letter could be. But, isn't it so, that it is our privilege, that we can be sad. "So sad that God is sad ..." You know who wrote it?

It goes like this: "The sad ones- but so sad that God is sad -Have royal silences.”

\footnotetext{
${ }^{41}$ I am so extremely sad/That even God feels said as Norwid said/But who am I to keep royal silence/And because of the sky through windows dawning/I howl, I really howl like a beaten dog/And on top of it I even don't have this poor/Certainty that as I howl, I am?

${ }^{42}$ C.K. Norwid, Poems - Letters - Drawings, op. cit., 31.
} 
In fact, we are silent-waiting. We live waiting for one line. That is why we live. And this line is a woman, isn't it so?

There is no solace for real sadness. For there is no solace for life. But sadness is great-we can be great through our sadness. Having put away our tools, we look at the Earth-we don't see the Earth, we see only ourselves in a great projection.

We forget what all words mean. We say: Pain, come. Torment! Pulsate. We are silent - and listen how pain pains. We wouldn't exist without this pain.

And you know all this. And it is the greatest solace to receive a truly sad letter. ${ }^{43}$

This reference to Norwid in the form of a letter and a dialogue with his poem, seems to be the most mature of all Wojaczek's receptions of Norwid. In the letter, which is also an interpretation of Norwid's poem, sadness and silence are accompanied by a soothing waiting for a woman, resembling the one described in the Norwidian erotic poems of Wojaczek, particularly in "The Window". In "A Morning Poem", which is, first of all, a confession, stripped of poetic aspects, rough, painfully non-metaphorical, appears "royal silence"-still great, connected with the dignity of silence and therefore out of the reach of the lyric 'I'; and so, in the letter we are silent- "we are silent-waiting. We live waiting for one line. That is why we live. And this line is a woman, isn't it so?"

"I am so extremely sad". In a similar fashion Norwid opened his poem "Aerumnarum Plenus" with the question "Why am I sad and what makes me most gloomy". ${ }^{44}$ In Wojaczek's poem, the first line of the last stanza is to establish a border, to introduce sadness, totally groundless in the first stanza: "Odbywając stosunki płciowe w miarę regularnie/Powiedziałbym częściej nawet niżli w jakiejś/ Nie ustanowionej zresztą, czy ja wiem, regule/W dodatku ilomaż sposobami ja to robię"("Having sexual intercourse more or less regularly/I would even say, more often than is some/Not established

43 R. Wojaczek, Listy do Stanisława Chacińskiego, „Odra” 1977, no. 5,. 92-93.

${ }^{44}$ Translated by Marcel Weyland. https://goo.gl/NNmgXv Retrieved 17.10.2018 
A. JARZYNA, "WOJACZEK: "NORWID SAYS HELLO..."

yet, how can I call it, a rule/And moreover, in how many different ways I do it!") and in the next line: "Wódkę pijąc już ponad wszelką miarę/ Będąc można rzec już zasłużonym/Weteranem pijackiego szlaku" ("While I drink vodka definitely beyond any measure/Being, so to say a renowned/Veteran of a drunks' trail"). And in the following one: "Mając za swoje stwierdzenie pana Przybosia/Że sztuka wiersza jest dźwignią poezji/Więc pilnie pracując nad doskonaleniem tej sztuki/ Pisując wiersze chyba częściej dobre niż złe/[...]Mogąc założyć się, że kilka z nich, tak z pięć/Może zmierzyć się z najlepszymi w swoim czasie" ("Accepting as my own Mr. Przybośs statement/That art is a lever of poetry/Working therefore diligently to make this art perfect/ Writing poems probably more often good than bad/[...] Willing to bet that several of them, let's say five/Can compete with the best written in this time.") (WZ, 294). These three stanzas are "anchors of reality" (WUZ, 9) - as Karpowicz called autobiographical allusions-details, which later would build the legend of the life of a scandalizing poet (his friends admit that he was an alcoholic, and sometimes drank cheap eau de cologne, although at the same time that he always had a very serious attitude to his own poetry). It is also clear that the last part of the poem, the Norwidian one, becomes the semantic dominant of the poem, the key to understanding it.

While writing in his letter about sadness as of a special privilege of man, Wojaczek was establishing a type of a community of sensitivity, a specific paradigm of male experiences, and included in it not only the addressee-Stanisław Chaciński-but also Norwid. Three years later he changed accents, but he did not call this old gesture an empty one. When he was quoting for the first time a fragment from Norwid's lyric poem, he was confessing his mood. For a moment Norwid was someone who understood him better than anyone else. Wojaczek referred to "My Song [I]" in his hospital journal in the same mannerat these two points the reception turns into a conversation to a higher degree than anywhere else. In "A Morning Poem" Norwid is quoted by someone else-someone older, in despair so deep that it is inhuman, a despair which does not know sublimation: "I howl, I really howl like a beaten dog/And on top of it I even don't have this poor/Certainty 
that as I howl, I am?" This howl, repeated in the last line, in the form of the internal rhyme, ostentatiously (especially for Wojaczek, who was so delicate with, for example, assonances) very exact ("wyję/żyję") (I howl/I live), sounds like a non-verbal-canine or human-howl. It is written in a different register-a non-Norwidian one, different than in the letter. There is a conviction in it that his (his lyric 'I's) sadness will not make him great, will not give him strength, or dignity; there is in this last word of the poem the defeat in the fight with his own despair.

Perhaps it is as late as in "A Wounded Poem", more than in "My Song (A.D. 1969)", that we have a clear identification of himself with Christ, who was not silent on the cross. This poem is the only trace of the change in Wojaczek's reception of Norwid, of the reversal from the way of reacting to pain through silence, which he had adopted in "My Song (A.D. 1969)" or in "Vademecum" and in the letter to Chaciński.

In conclusion, I would like to stress once again (I have attempted to signal it many times in this text) that references to Norwid, although important for Wojaczek (his private notes testify such a claim) are not numerous. Most of the Norwidian poems of Wojaczek were published posthumously. ${ }^{45}$ Wojaczek mentioned Norwid by name three times, but only once in a published poem-in the volume $A n$ Unfinished Crusade. It takes the form of reminiscence, a light touch (but non erasable, thanks to enjambment) in the poem "Gdy pies

45 As Bogusław Kierc's editiorial note to Wojaczek's Collected Poems indicates [Nota edytorska do Utworów zebranych] (WUZ, 361-372), the decision not to include 'Norwidian poems' (which happened to other poems) was not taken by censors or by editors. It seems that most of the lyric poems I focus on here ("The Rest of Blood", "Generalities", "Vademecum" "My Song (A.D. 1969)" simply were not intended to be published; only "A Rose" was included in versions of An Unfinished Crusade, finally (after 1970) Wojaczek crossed it out, while the poems "Calm Down, My Sleep, She Is Not Here" "When Dog's Moon" and "Can a Sleeping Woman be Woken up Gently" were not included in the first versions of Wojaczek's volume. As if Wojaczek (his final decision to remove "A Rose" from the volume confirms this) avoided too obvious associations with Norwid, and poems in which he referred to Norwid's poetry were considered by him as some private line of his poetry. 
A. JARZYNA, "WOJACZEK: "NORWID SAYS HELLO..."

księżyca" ("When the Dog's Moon"): "When, as Norwid, you state that you are not well acquainted with theory."(WZ, 101). It was here that Wojaczek made a mistake, and this mistake seems to be emblematic. Wojaczek, in the long poem Do Bronisława Z. (To Bronisław Z.) used the phrase ("A master mean in theories") to refer to Mickiewicz. This mistake happened to a poet who was inspired by the first sentence of Silence - a theoretical treatise by Norwid-a poet who-as Andrzej Niewiadomski showed-built his meta-commentaries in reference to his texts.

Wojaczek has a special place in the midst of writers who have been inspired by Norwid. He was not a poet of Norwidian idiom, but their paths met in similar approaches to the capabilities and responsibilities of poetry and in similar approaches to the figure of the crucified Christ. But Wojaczek was, first of all-and the words I am quoting in the title confirm this-a reader who read more than once, and was therefore an interpreter of Norwid's poems, an aficionado of a few selected phrases. 